\title{
HUBUNGAN KONSUMSI ALKOHOL DENGAN CEDERA DISEBABKAN KECELAKAAN LALU LINTAS DI INDONESIA TAHUN 2018 (ANALISIS DATA RISKESDAS 2018)
}

\author{
Alcohol Consumption and Injury \\ Caused by Traffic Accident in Indonesia in 2018 \\ (Analysis of 2018 Riskesdas Data)
}

\author{
Khairun Nisa'il Hulwah', Wahyu Pudji Nugraheni ${ }^{2}$, Andi Sari Bunga ${ }^{3}, K^{1}$ urnia Sari ${ }^{1}$, Pujiyanto $^{1}$, Budi Hidayat $^{1}$ \\ ${ }^{1}$ Fakultas Kesehatan Masyarakat, Universitas Indonesia \\ ${ }^{2}$ Puslitbang Humaniora dan Manajemen Kesehatan, Badan Litbang Kesehatan \\ ${ }^{3}$ Direktorat Promosi Kesehatan, Kementerian Kesehatan
}

Naskah masuk: 24 Agustus 2020 Perbaikan: 28 Desember 2020 Layak terbit: 1 Februari 2021

https://doi.org/10.22435/hsr.v24i1.3707

\begin{abstract}
ABSTRAK
Kejadian cedera meningkat dari 7,5\% menjadi 9,2\% (2007-2018). Proporsi cedera akibat kecelakaan lalu lintas di Indonesia sebesar 2,2\% dan paling tinggi pada usia 15-24 tahun sebesar 4,9\%. Total konsumsi alkohol per kapita diperkirakan meningkat di Indonesia tahun 2025. Perilaku mengonsumsi minuman beralkohol meningkatkan risiko kecelakaan lalu lintas. Penelitian ini bertujuan untuk mengetahui hubungan dan besaran risiko perilaku konsumsi minuman beralkohol dengan kejadian cedera disebabkan kecelakaan lalu lintas pada penduduk usia $>10$ tahun di Indonesia. Penelitian ini merupakan penelitian kuantitatif dengan menggunakan analisis univariat, bivariat, dan multivariat. Hasil multivariat penelitian menunjukkan hubungan yang signifikan antara konsumsi minuman beralkohol dengan cedera disebabkan kecelakaan lalu lintas dengan OR 2,436 (95\% Cl: 1,233 - 4,811) setelah dikontrol oleh variabel lain yaitu variabel umur, jenis kelamin, pendidikan, pekerjaan, wilayah tempat tinggal dan pulau domisili. Kelompok laki-laki berhubungan bermakna dengan OR 1,204 (95\% Cl:1,131 - 1,282), pendidikan tinggi berhubungan bermakna dengan OR 1,953 (95\% Cl: 1,783 - 2,138), bekerja berhubungan bermakna dengan OR 1,230 (95\% Cl: 1,138 - 1,329), tinggal di perkotaan berhubungan bermakna dengan OR 1,176 (95\% Cl: 1,104 - 1,253) dan domisili di Pulau Sulawesi berhubungan bermakna dengan OR 1,811 (95\% Cl: 1,580 - 2,077). Variabel umur tidak signifikan. Variabel konsumsi alkohol adalah variabel yang paling besar pengaruhnya terhadap cedera disebabkan kecelakaan lalu lintas. Perlu fokus intervensi terhadap kelompok penduduk yang lebih berisiko dalam merumuskan kebijakan dan program kesehatan untuk menurunkan kejadian cedera disebabkan kecelakaan lalu lintas.
\end{abstract}

Kata Kunci: Cedera; kecelakaan Ialu lintas; konsumsi alkohol

\section{ABSTRACT}

The incidence of injury increased from $7.5 \%$ to $9.2 \%$ (2007-2018). The proportion of injuries due to traffic accidents in Indonesia is $2.2 \%$ and the highest is at $15-24$ years of age at $4.9 \%$. Total per capita alcohol consumption is expected to increase in Indonesia by 2025. The behavior of consuming alcoholic beverages increases the risk of traffic accidents. This study aimed to determine the relationship and the magnitude of the risk of alcohol consumption behavior with the incidence of injuries caused by traffic accidents in people aged >10 years in Indonesia. This research was a quantitative study using univariate, bivariate, and multivariate analysis. The multivariate results of the study showed a significant

Korespondensi:

Khairun Nisa'il Hulwah

Fakultas Kesehatan Masyarakat, Universitas Indonesia

E - mail : nisail.khairun81@gmail.com 
relationship between alcohol consumption and injuries caused by traffic accidents with OR 2.436 (95\% Cl: 1.233 - 4.811) after being controlled by other variables, namely age, sex, education, occupation, area of residence and island of domicile. Male group had a significant relationship with OR 1.204 (95\% Cl: 1.131 - 1.282), higher education was significantly associated with OR 1.953 (95\% Cl: 1.783 - 2.138), work was significantly associated with OR 1.230 (95\% Cl: 1.138 - 1.329) ), living in urban areas was significantly associated with OR 1.176 (95\% Cl: 1.104 - 1.253) and domicile in Sulawesi Island was significantly associated with OR 1.811 (95\% Cl: 1.580 - 2.077). The age variable is not significant. Alcohol consumption is the variable that has the greatest influence on injuries caused by traffic accidents. Interventions need to be focused on population groups who are more at risk in formulating health policies and programs to reduce the incidence of injuries caused by traffic accidents.

Keywords: Injury; traffic accidents; alcohol consumption

\section{PENDAHULUAN}

Cedera adalah masalah kesehatan masyarakat yang penting. Lima juta orang lebih $(9 \%)$ meninggal pertahun akibat cedera. Cedera utama yang menyebabkan kematian di dunia adalah kecelakaan lalu lintas (24\%). Sebelumnya telah diperkirakan, berdasarkan disability adjusted life year (DALY), kecelakaan lalu lintas menempati urutan ketiga di tahun 2020 (Nantulya, 2002), sedangkan di negara berkembang menempati urutan kedua (Coats, 2002). Cedera akibat kecelakaan lalu lintas merupakan penyebab utama disabilitas dan mortalitas di negara berkembang (Riyadina, 2007). Di Indonesia, tren kejadian cedera cenderung meningkat tahun 2007-2018 yaitu $7,5 \%$ menjadi 9,2\% (Balitbangkes, 2019). Proporsi cedera disebabkan kecelakaan lalu lintas di Indonesia yaitu 2,2\% dan paling tinggi pada usia 15-24 tahun sebesar 4,9\% (Balitbangkes, 2019).

Setiap tahun terdapat sekitar 1,35 juta orang meninggal di dunia karena kecelakaan lalu lintas (WHO, 2020). Indonesia adalah tertinggi kelima di dunia jumlah kematian akibat kecelakaan lalu lintas tahun 2016, yaitu sebanyak 31.282 orang (World Health Organization, 2018). Menurut Korps Lalu Lintas Kepolisian Republik Indonesia (Korlantas POLRI), selama kurun waktu 2014-2018, jumlah kecelakaan lalu lintas di Indonesia mengalami kenaikan rata-rata 3,30\% per tahun (Badan Pusat Statistik, 2019).

Menurut Haddon (1968), kejadian kecelakaan lalu lintas disebabkan oleh faktor manusia, kendaraan dan lingkungan. Faktor pengemudi (95\%) menjadi penyebab dominan kecelakaan lalu lintas (Petridou dan Moustaki, 2000). Green (1980) menyebutkan bahwa ada tiga faktor perilaku kesehatan manusia yaitu faktor predisposisi, faktor pendukung dan faktor pendorong. Faktor predisposisi adalah ciri-ciri yang telah ada pada individu sebelum menderita sakit. Faktor ini berkaitan dengan karakteristik individu yang mencakup ciri demografi, struktur sosial, sikap dan keyakinan. Salah satu perilaku berisiko ketika mengemudi adalah mengonsumsi minuman beralkohol. Perilaku mengonsumsi minuman beralkohol meningkatkan risiko kecelakaan lalu lintas (Pan American Health Organization , 2018).

Total konsumsi alkohol per kapita diperkirakan meningkat di separuh wilayah WHO hingga tahun 2025. Peningkatan tertinggi terjadi di wilayah Asia Tenggara dengan peningkatan 2,2 liter di India, sebagai representasi populasi terbesar. Peningkatan juga diperkirakan terjadi di Indonesia dan Thailand sebagai representasi populasi terbesar kedua dan keempat (World Health Organization 2018). Di Indonesia, proporsi konsumsi minuman beralkohol pada penduduk $>10$ tahun yaitu 3,3\% dengan lima Provinsi tertinggi di atas $10 \%$ yaitu: Sulawesi Utara, Nusa Tenggara Timur (NTT), Bali, Gorontalo dan Maluku (Balitbangkes, 2019).

WHO melalui Global Action Plan on Sustainable Development Goals (SGDs) 2013-2030 memberi arahan untuk melaksanakan 17 tujuan SDGs, dimana terdapat tujuan ke-3 yaitu "menjamin kehidupan yang sehat dan mendorong kesejahteraan bagi semua orang di segala usia". Dalam konteks ini, WHO menargetkan untuk menurunkan konsumsi alkohol setidaknya menjadi $10 \%$ pada setiap negara dan menurunkan angka kematian yang disebabkan kecelakaan lalu lintas sebanyak 50\% (WHO, 2018). Melihat tingginya angka kematian akibat kecelakaan lalu lintas dan 
konsumsi alkohol mengindikasikan perlunya lebih banyak perhatian dari pemerintah dan stakeholders terkait agar tercapai tujuan SDGs ini. Artikel ini bertujuan untuk mengetahui hubungan konsumsi alkohol dengan cedera disebabkan kecelakaan lalu lintas. Dilihat pula gambaran karakteristik sosial demografi (umur, jenis kelamin, pendidikan, pekerjaan, wilayah tempat tinggal, pulau tempat tinggal) responden yang mengalami cedera disebabkan kecelakaan lalu lintas dan yang mengonsumsi alkohol.

\section{METODE}

Artikel ini merupakan penelitian kuantitatif dengan menggunakan Riset Kesehatan Dasar (Riskesdas) 2018 yang diambil dari hasil penelitian dari Laboratorium Manajemen Data Badan Litbangkes Kementerian Kesehatan. Riskesdas 2018 dilaksanakan di 34 provinsi di Indonesia secara cross sectional (potong lintang). Penelitian ini dilaksanakan pada bulan April-Juni 2020. Besar sampel penelitian adalah 26.819 responden usia > 10 tahun yang mengalami cedera. Kriteria inklusi adalah mengalami cedera sebagai variabel dependen dan mempunyai data informasi tentang perilaku konsumsi alkohol sebagai variabel independen. Variabel kovariat adalah sosial demografi meliputi umur, jenis kelamin, pendidikan, pekerjaan, wilayah tempat tinggal dan pulau domisili.

Keterbatasan dalam analisis data sekunder adalah adalah karena pertanyaan-pertanyaan dalam kuesioner sudah baku dan tidak dapat diubah lagi. Desain penelitian cross sectional tidak mengenal dimensi waktu karena eksposure dan outcome pengamatan dilakukan dalam satu waktu. Kerangka konsep yang digunakan adalah Teori Kecelakaan Lalu Lintas Haddon (1968) pada faktor manusia dan Teori Perilaku Green (1980) pada faktor predisposisi dan faktor pendukung. Alur pemilihan sampel dalam penyusunan artikel ini adalah responden yang mengalami cedera (26.819 orang). Gambar 1 menunjukkan alur pemilihan sampel.

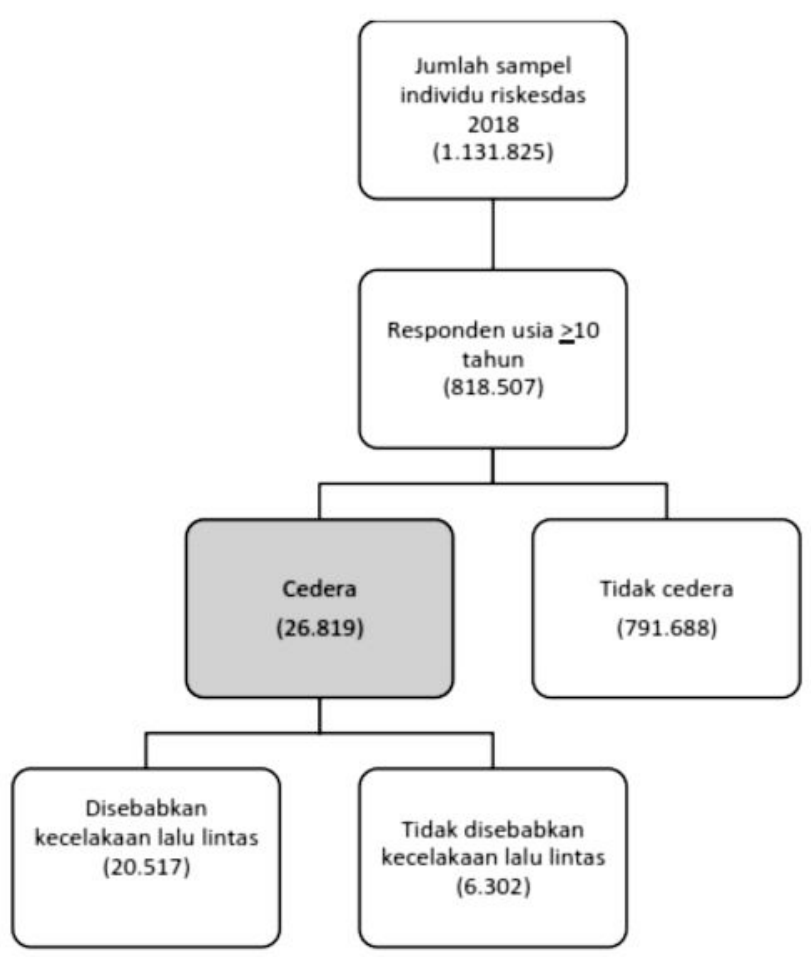

Gambar 1 Alur Pemilihan Sampel 
Variabel cedera diambil dari Kuesioner Riskesdas Blok X Kode E06-E07 yang berisi pertanyaan, "apakah cedera disebabkan karena kecelakaan lalu lintas?". Variabel ini dikelompokkan dalam kategori "ya" dan "tidak". Variabel perilaku konsumsi alkohol diambil dari Kuesioner Riskesdas Blok X Kode G35-G38 yang berisi pertanyaan, "apakah mengonsumsi minuman beralkohol dalam 1 bulan terakhir?". Variabel ini juga dikelompokkan dalam kategori "ya" dan "tidak". Variabel sosial demografi dikelompokkan dalam berbagai kategorik. Umur dibagi menjadi remaja (10-25 tahun), dewasa (26-45 tahun) dan lansia (46-112 tahun). Jenis kelamin menjadi dua kelompok yaitu laki-laki dan perempuan. pendidikan dibagi menjadi tiga kelompok yaitu rendah (tidak sekolah/tamat SD), sedang (tamat SMP/tidak tamat SMA), dan tinggi (tamat SMA/tamat Perguruan Tinggi). Pekerjaan dibagi menjadi dua kelompok yaitu bekerja dan tidak bekerja. Wilayah dibagi dua kelompok yaitu perkotaan dan pedesaan. Dan pulau dibagi enam kelompok yaitu Sumatera, Jawa, Bali dan Nusa Tenggara, Kalimantan, Sulawesi, Maluku dan Papua.

HASIL

\section{Gambaran Distribusi Frekuensi Variabel}

Hasil analisis univariat menunjukkan bahwa sebagian besar kejadian cedera pada responden disebabkan oleh kecelakaan lalu lintas (76,5\%). Sebagian besar responden tidak mengonsumsi minuman beralkohol $(90,10 \%)$, berusia remaja $(48,80 \%)$, jenis kelamin laki-laki $(61,80 \%)$, memiliki tingkat pendidikan sedang $(45,50 \%)$, memiliki status bekerja $(52,70 \%)$, tinggal di wilayah pedesaan $(54,50 \%)$, dan berasal dari Pulau Jawa $(30,80 \%)$. Tabel 1 menunjukkan analisis univariat.

Tabel 1 Distribusi Responden menurut Karakteristik Variabel

\begin{tabular}{|c|c|c|c|}
\hline \multicolumn{2}{|c|}{ Variabel } & $\underset{(n=26819)}{\text { Jumlah }}$ & $\begin{array}{c}\text { Persentase } \\
\%\end{array}$ \\
\hline \multirow{2}{*}{ Kecelakaan lalu lintas } & $\mathrm{Ya}$ & 20.517 & 76,5 \\
\hline & Tidak & 6.302 & 23,5 \\
\hline \multirow[t]{2}{*}{ Konsumsi Alkohol } & $\mathrm{Ya}$ & 2.658 & 9,90 \\
\hline & Tidak & 24.161 & 90,10 \\
\hline \multirow[t]{3}{*}{ Umur } & Remaja (10-25 tahun) & 13.085 & 48,80 \\
\hline & Dewasa (26-45 tahun) & 8.369 & 31,20 \\
\hline & Lansia (46-112 tahun) & 5.365 & 20,00 \\
\hline \multirow{2}{*}{ Jenis kelamin } & Laki-laki & 16.574 & 61,80 \\
\hline & Perempuan & 10.245 & 38,20 \\
\hline \multirow[t]{3}{*}{ Pendidikan } & $\begin{array}{l}\text { Rendah (tidak } \\
\text { sekolah/tamat SD) }\end{array}$ & 4.225 & 15,80 \\
\hline & $\begin{array}{l}\text { Sedang (tamat } \\
\text { SMP/tidak tamat SMA) }\end{array}$ & 13.274 & 49,50 \\
\hline & $\begin{array}{l}\text { Tinggi (tamat } \\
\text { SMA/tamat Perguruan } \\
\text { Tinggi) }\end{array}$ & 9.320 & 34,80 \\
\hline \multirow[t]{2}{*}{ Pekerjaan } & Bekerja & 14.130 & 52,70 \\
\hline & Tidak bekerja & 12.689 & 47,30 \\
\hline \multirow{2}{*}{ Wilayah tempat tinggal } & Pedesaan & 14.618 & 54,50 \\
\hline & Perkotaan & 12.201 & 45,50 \\
\hline \multirow[t]{6}{*}{ Pulau domisili } & Sumatera & 6.835 & 25,50 \\
\hline & Jawa & 8.251 & 30,80 \\
\hline & Bali dan Nusa Tenggara & 2.638 & 9,80 \\
\hline & Kalimantan & 2.446 & 9,10 \\
\hline & Sulawesi & 4.967 & 18,50 \\
\hline & Maluku dan Papua & 1.682 & 6,27 \\
\hline
\end{tabular}


Hubungan Konsumsi Alkohol dengan Cedera disebabkan Kecelakaan Lalu Lintas

Hasil analisis bivariat menunjukkan bahwa terdapat hubungan yang bermakna $(p<00.5)$ antara semua variabel dengan cedera disebabkan kecelakan lalu lintas. Responden yang mengonsumsi minuman beralkohol berisiko 1,364 kali dibandingkan yang tidak mengonsumsi minuman beralkohol. Tabel 2 menunjukkan analisis bivariat.

Tabel 2 Analisis Bivariat Konsumsi Minuman Beralkohol dan Faktor Lainnya dengan Cedera disebabkan Kecelakaan Lalu Lintas pada Responden Usia $\geq 10$ tahun di Indonesia Tahun 2018

\begin{tabular}{|c|c|c|c|c|c|c|c|c|}
\hline \multirow{3}{*}{ Variabel } & \multicolumn{4}{|c|}{ Cedera disebabkan Kecelakaan Lalu Lintas } & \multirow{2}{*}{\multicolumn{2}{|c|}{ Total }} & \multirow{3}{*}{$P$ value } & \multirow{3}{*}{ OR $(95 \% \mathrm{Cl})$} \\
\hline & \multicolumn{2}{|c|}{$\mathrm{Ya}$} & \multicolumn{2}{|c|}{ Tidak } & & & & \\
\hline & $\mathbf{N}$ & $\%$ & $\mathbf{N}$ & $\%$ & $\mathrm{n}$ & $\%$ & & \\
\hline \multicolumn{9}{|c|}{ Konsumsi Minuman Beralkohol } \\
\hline Ya & 2.158 & 81,19 & 500 & 18,81 & 2.658 & 100 & \multirow{2}{*}{0,001} & 1,364 \\
\hline Tidak (ref) & 18.359 & 75,99 & 5.802 & 24,01 & 24.161 & 100 & & $(1,232-1,510)$ \\
\hline \multicolumn{9}{|l|}{ Umur } \\
\hline Remaja & 9.873 & 75,45 & 3.212 & 24,55 & 13.085 & 100 & \multirow{3}{*}{0,001} & $\begin{array}{c}1,004 \\
(0,933-1,081)\end{array}$ \\
\hline Dewasa & 6.600 & 78,86 & 1.769 & 21,14 & 8.369 & 100 & & $\begin{array}{c}1,219 \\
(1,124-1,322)\end{array}$ \\
\hline Lansia (ref) & 4.044 & 75,38 & 1.321 & 24,62 & 5.365 & 100 & & 1 \\
\hline \multicolumn{9}{|l|}{ Jenis Kelamin } \\
\hline Laki-laki & 12.966 & 78,23 & 3.608 & 21,77 & 16.574 & 100 & \multirow{2}{*}{0,001} & 1,282 \\
\hline Perempuan (ref) & 7.551 & 73,70 & 2.694 & 26,30 & 10.245 & 100 & & $(1,211-1,358)$ \\
\hline \multicolumn{9}{|l|}{ Pendidikan } \\
\hline Rendah (ref) & 2.839 & 67,20 & 1.386 & 32,80 & 4.225 & 100 & \multirow{3}{*}{0,001} & 1 \\
\hline Sedang & 10.137 & 76,37 & 3.137 & 23,69 & 13.274 & 100 & & $\begin{array}{c}1,578 \\
(1,463-1,702) \\
\end{array}$ \\
\hline Tinggi & 7.541 & 80,91 & 1.779 & 19,09 & 9.320 & 100 & & $\begin{array}{c}2,069 \\
(1,906-2,247)\end{array}$ \\
\hline \multicolumn{9}{|l|}{ Pekerjaan } \\
\hline Bekerja & 11.173 & 79,07 & 2.957 & 20,93 & 14.130 & 100 & \multirow{2}{*}{0,001} & 1,353 \\
\hline Tidak Bekerja (ref) & 9.344 & 73,64 & 3.345 & 26,36 & 12.689 & 100 & & $(1,278-1,431)$ \\
\hline \multicolumn{9}{|c|}{ Wilayah Tempat Tinggal } \\
\hline Perkotaan & 9.581 & 78,50 & 2.620 & 21,50 & 12.201 & 100 & \multirow{2}{*}{0,001} & 1,231 \\
\hline Pedesaan (ref) & 10.936 & 74,80 & 3.682 & 25,20 & 14.618 & 100 & & $(1,163-1,304)$ \\
\hline \multicolumn{9}{|l|}{ Pulau Domisili } \\
\hline Sumatera & 5.179 & 75,80 & 1.656 & 24,20 & 6.835 & 100 & \multirow{6}{*}{0,001} & $\begin{array}{c}1,293 \\
(1,148-1,456)\end{array}$ \\
\hline Jawa & 6.351 & 77,00 & 1.900 & 23,00 & 8.251 & 100 & & $\begin{array}{c}1,382 \\
(1,230-1,553)\end{array}$ \\
\hline $\begin{array}{l}\text { Bali dan Nusa } \\
\text { Tenggara }\end{array}$ & 2.061 & 78,10 & 577 & 21,90 & 2.638 & 100 & & $\begin{array}{c}1,477 \\
(1,284-1,698)\end{array}$ \\
\hline Kalimantan & 1.774 & 72,50 & 672 & 27,50 & 2.446 & 100 & & $\begin{array}{c}1,091 \\
(0,951-1,252)\end{array}$ \\
\hline Sulawesi & 3.962 & 79,80 & 1.005 & 20,20 & 4.967 & 100 & & $\begin{array}{c}1,630 \\
(1,437-1,848)\end{array}$ \\
\hline $\begin{array}{l}\text { Maluku dan Papua } \\
\text { (ref) }\end{array}$ & 1.190 & 70,70 & 492 & 29,30 & 1.682 & 100 & & 1 \\
\hline
\end{tabular}


Hubungan Konsumsi Alkohol dengan Cedera disebabkan Kecelakaan Lalu Lintas dipengaruhi Variabel Kovariat

Analisis multivariat memperlihatkan hubungan secara statistik bermakna $(p<0,05)$ antara konsumsi minuman beralkohol dengan cedera disebabkan kecelakaan lalu lintas yaitu dengan nilai OR 2,436 (95\% Cl: 1,233 - 4,811) setelah dikontrol variabel lain. Hasil interaksi konsumsi alkohol dengan variabel lain memperlihatkan bahwa secara statistik bermakna $(p<0,05)$ hubungan antara responden yang mengonsumsi alkohol berdasarkan kelompok pendidikan dan pulau domisili dengan cedera disebabkan kecelakaan lalu lintas. Tabel 3 menunjukkan analisis multivariat.

Tabel 3 Pemodelan Lengkap Hubungan Konsumsi Alkohol dengan Cedera disebabkan Kecelakaan Lalu Lintas

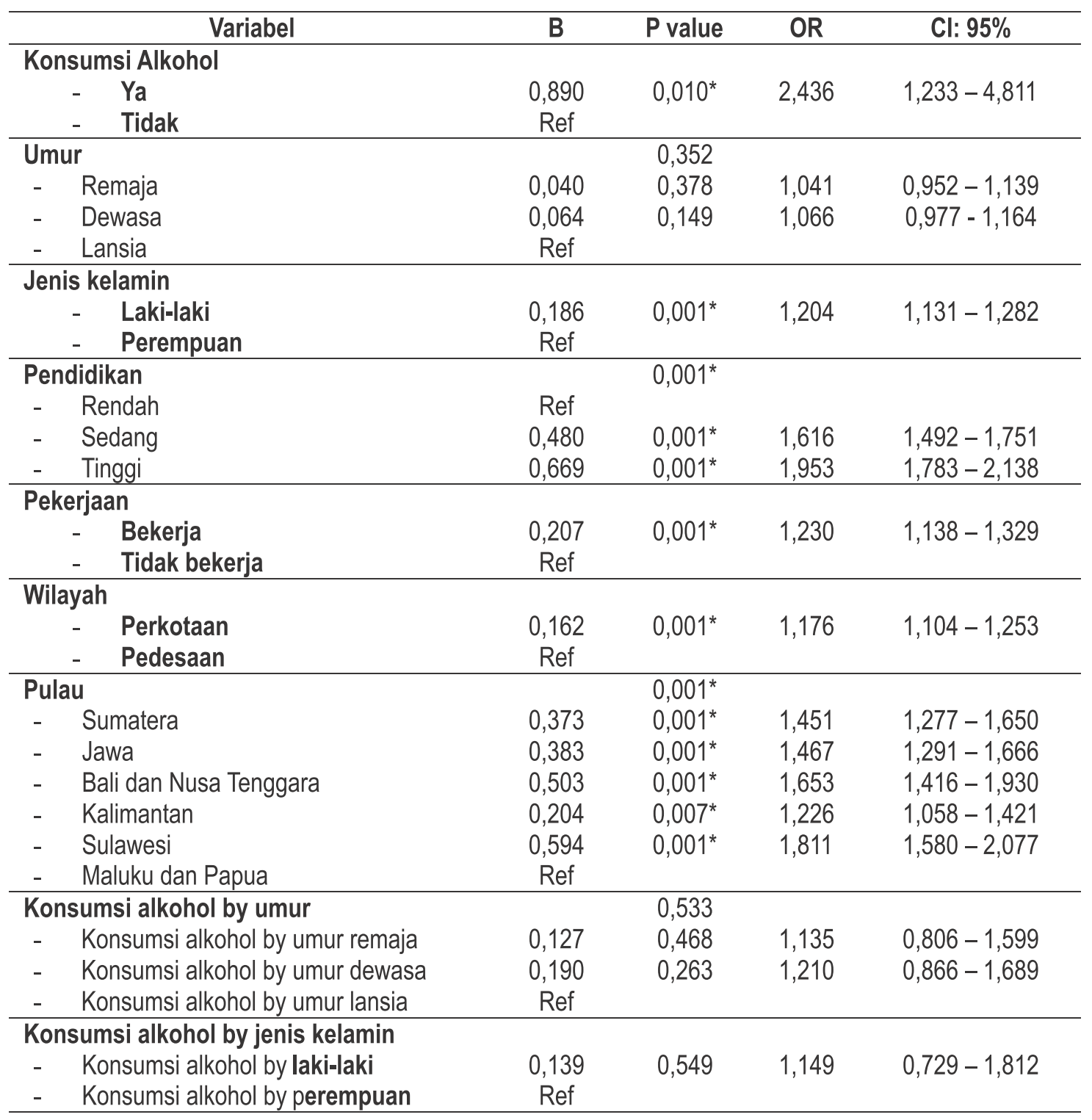




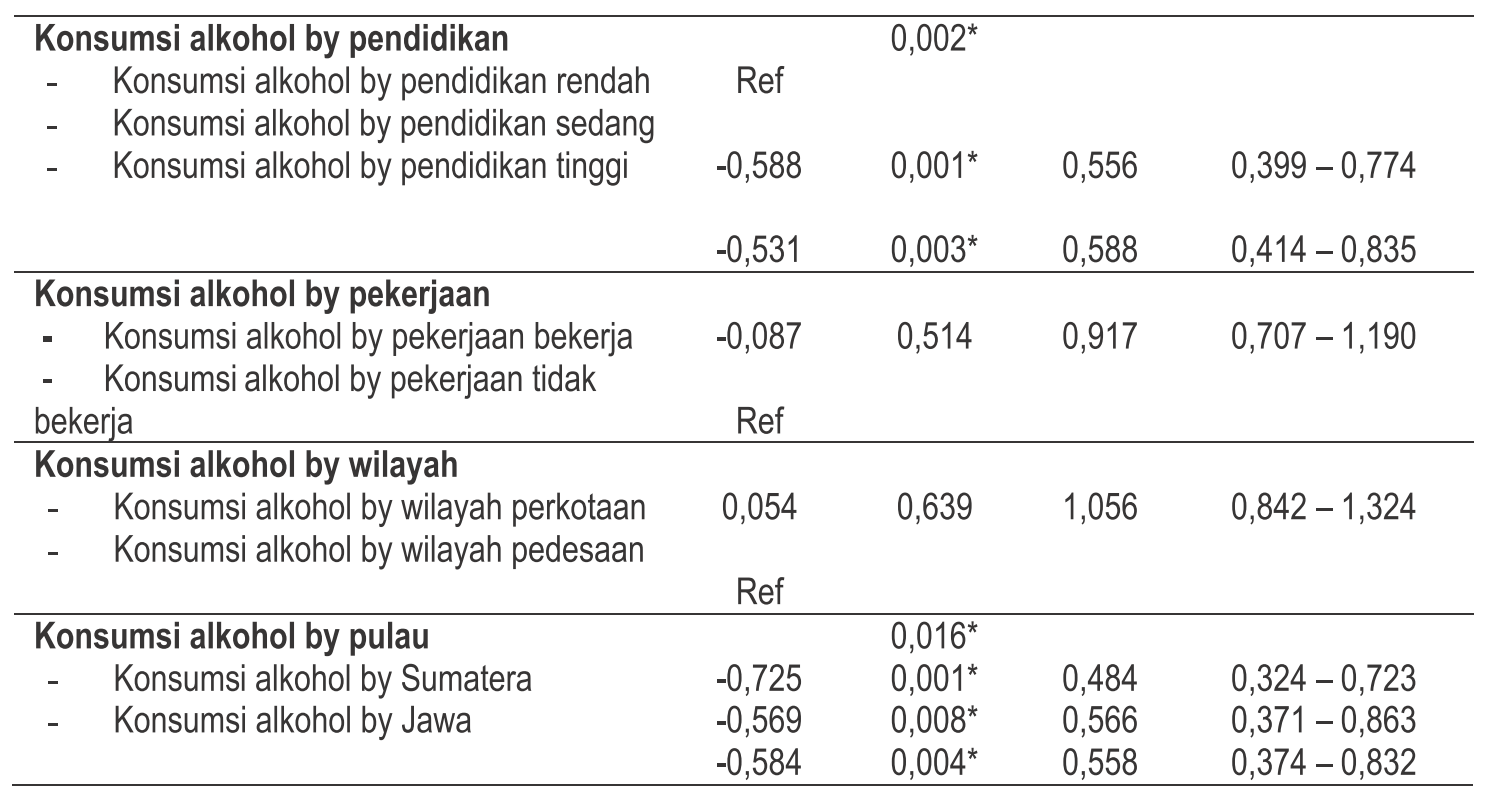

Hasil interaksi konsumsi minuman beralkohol dengan variabel kovariat. Peningkatan risiko cedera disebabkan kecelakaan lalu lintas terlihat pada kelompok responden dewasa $(\mathrm{OR}=2,945)$, laki-laki $(\mathrm{OR}=2,798)$, dan tinggal di perkotaan $(\mathrm{OR}=2,570)$. Responden dewasa yang mengonsumsi minuman beralkohol tidak bermakna secara statistik $(p>0,05)$ namun berisiko 2,945 kali untuk mengalami cedera disebabkan kecelakaan lalu lintas dibandingkan responden lansia. Responden laki-laki yang mengonsumsi minuman beralkohol tidak bermakna secara statistik $(p>0,05)$ berisiko 2,798 kali untuk mengalami cedera disebabkan kecelakaan lalu lintas dibandingkan responden perempuan. Responden yang tinggal di perkotaan tidak bermakna secara statistik $(p>0,05)$ namun berisiko 2,570 kali untuk mengalami cedera disebabkan kecelakaan lalu lintas yang tinggal di pedesaan. Pada kelompok responden berdasarkan pendidikan, pekerjaan, dan pulau domisili terlihat bahwa risiko cedera disebabkan kecelakaan lalu lintas semakin rendah pada tingkat pendidikan sedang, bekerja, dan tinggal di Pulau Sumatera. Tabel 4 menunjukkan perhitungan OR Variabel Interaksi.

Tabel 4 Perhitungan OR Variabel Interaksi

\begin{tabular}{lcc}
\hline \multicolumn{1}{c}{ Variabel } & Perhitungan & OR \\
\hline Konsumsi alkohol by umur & $e^{(0,890)(1)+(0,127)(1)}$ & 2,765 \\
\hline Konsumsi alkohol, umur remaja & $e^{(0,890)(1)+(0,190)(1)}$ & $\mathbf{2 , 9 4 5}$ \\
\hline Konsumsi alkohol, umur dewasa & $e^{(0,890)(1)}$ & $2,435^{*}$ \\
\hline Konsumsi alkohol, umur lansia* & $e^{(0,890)(1)+(0,139)(1)}$ & $\mathbf{2 , 7 9 8}$ \\
\hline Konsumsi alkohol by jenis kelamin & $e^{(0,890)(1)}$ & $2,435^{*}$ \\
\hline Konsumsi alkohol, laki-laki & $e^{(0,890)(1)}$ & $\mathbf{2 , 4 3 5 ^ { * }}$ \\
\hline Konsumsi alkohol, perempuan* & 1,353 \\
\hline Konsumsi alkohol by pendidikan & $e^{(0,890)(1)+(-0,588)(1)}$ & 1,432 \\
\hline Konsumsi alkohol, pendidikan rendah* & $e^{(0,890)(1)+(-0,531)(1)}$ & 2,232 \\
\hline Konsumsi alkohol, pendidikan sedang & $e^{(0,890)(1)+(-0,087)(1)}$ & $\mathbf{2 , 4 3 5 ^ { * }}$ \\
\hline Konsumsi alkohol, pendidikan tinggi & $e^{(0,890)(1)}$ & \\
\hline Konsumsi alkohol by pekerjaan & & \\
\hline Konsumsi alkohol, bekerja & & \\
\hline
\end{tabular}




\begin{tabular}{lcc} 
Konsumsi alkohol by wilayah & & \\
\hline Konsumsi alkohol, perkotaan & $e^{(0,890)(1)+(0,054)(1)}$ & $\mathbf{2 , 5 7 0}$ \\
\hline Konsumsi alkohol, pedesaan* & $e^{(0,890)(1)}$ & $2,435^{\star}$ \\
\hline Konsumsi alkohol by pulau & $e^{(0,890)(1)+(-0,725)(1)}$ & 1,179 \\
\hline Konsumsi alkohol, Sumatera & $e^{(0,890)(1)+(-0,569)(1)}$ & 1,379 \\
\hline Konsumsi alkohol, Jawa & $e^{(0,890)(1)+(-0,584)(1)}$ & 1,358 \\
\hline Konsumsi alkohol, Bali dan Nusa Tenggara & $e^{(0,890)(1)+(-0,505)(1)}$ & 1,470 \\
\hline Konsumsi alkohol, Kalimantan & $e^{(0,890)(1)+(-0,411)(1)}$ & 1,614 \\
\hline Konsumsi alkohol, Sulawesi & $e^{(0,890)(1)}$ & $\mathbf{2 , 4 3 5 ^ { * }}$ \\
\hline Konsumsi alkohol, Maluku dan Papua* & & \\
\hline *referensi & &
\end{tabular}

\section{PEMBAHASAN}

\section{Gambaran Kejadian Cedera disebabkan Kecelakaan Lalu Lintas}

Pada penelitian ini ditemukan bahwa, secara nasional, terdapat $3,3 \%$ kejadian cedera dari responden usia $>10$ tahun. Dari total kejadian cedera, sebanyak $76,5 \%$ disebabkan oleh kecelakaan lalu lintas. Jadi, angka nasional kejadian cedera yang disebabkan kecelakaan lalu lintas pada responden > 10 tahun adalah 2,5\%. Jika dibandingkan dengan data jumlah korban kecelakaan lalu lintas tahun 2018 dari Korlantas yang hanya 173.358 orang, jumlah ini sangat kecil sekali dibandingkan dengan angka hasil estimasi data Riskesdas 2018 yaitu hanya $3,2 \%$. Menurut Utama (2008), estimasi prevalensi kecelakaan lalu lintas berbeda secara nyata dan lebih besar dibandingkan prevalensi kecelakaan lalu lintas di kepolisian dan rumah sakit dengan potensi data kurang (under reporting) di kepolisian (724\%) lebih besar dari rumah sakit (229\%). Penelitian di Kabupaten Jember (Ajie, 2017) menemukan sistem informasi untuk pencatatan data kecelakaan lalu lintas yang terintegrasi dari instansi berbeda.

Penyebab kecelakaan lalu lintas terbesar adalah mengendarai sepeda motor sebesar $72,7 \%$ (Balitbangkes, 2019). Sepeda motor banyak digunakan sebagai sarana aktivitas kerja karena jenis kendaraan yang praktis dan irit (Kurniasih, 2013). Pengendara sepeda motor berisiko 34 kali mengalami kecelakaan yang mengakibatkan kematian dan delapan kali mengalami cedera dibanding kendaraan lain (Lin, 2009). Angka ini didukung dengan data distribusi kematian di jalan di wilayah Asia Tenggara yaitu sebagian besar (43\%) terjadi pada kendaraan bermotor roda dua dan tiga (Lin, 2009).

Masalah kecelakaan lalu lintas semakin menjadi perhatian karena persentase yang tinggi pada kejadian cedera. Dari seluruh kematian yang disebabkan oleh cedera di dunia, 24\% berasal dari kecelakaan lalu lintas (WHO, 2014). Jumlah kecelakaan lalu lintas cendrung meningkat yaitu dari 95.906 kejadian tahun 2014, menjadi 109.215 kejadian tahun 2018 di Indonesia (Badan Pusat Statistik, 2019). Jumlah kendaraan bermotor yang dimiliki penduduk Indonesia juga meningkat setiap tahunnya. Pertumbuhan per tahun pada mobil penumpang, bis, mobil barang, dan sepeda motor masing-masing 6,88\%; 1,42\%; 5,68\%; dan 6,61\% (Badan Pusat Statistik, 2019).

Penyebab kecelakaan lalu lintas salah satunya adalah faktor manusia. Menurut Petridou dan Moustaki (2000), faktor dominan penyebab kecelakaan lalu lintas adalah kesalahan perilaku pengemudi (95\%). Konsumsi alkohol adalah salah satu faktor yang menimbulkan kesalahan perilaku manusia. Sebanyak 5-35\% kematian yang terjadi di jalan adalah karena alkohol (Pan American Health Organization, 2018).

Kelompok umur dewasa lebih banyak mengalami cedera disebabkan kecelakaan lalu lintas. Kelompok masyarakat usia $<45$ tahun lebih banyak mendapat cedera akibat kecelakaan sepeda motor (Mariana, 2018). Cedera akibat kecelakaan motor lebih banyak pada kelompok umur muda (20-49 tahun) disebabkan karena jumlah pengguna sepeda motor yang besar pada kelompok umur ini dibandingkan kelompok umur lain (Hosseinpour, 2017). Sebanyak 82,5\% karyawan usia 20-50 tahun pernah mengalami kecelakaan lalu lintas (Meirinda, 2017). Kecelakaan lalu lintas merupakan salah satu penyebab kematian utama kelompok umur 15-44 tahun (Sulistiyowati, 2012).

\section{Hubungan Konsumsi Alkohol dan Faktor Sosial Demografi dengan Cedera disebabkan Kecelakaan Lalu Lintas}

Hubungan konsumsi minuman beralkohol dengan cedera disebabkan kecelakaan lalu lintas 
dikontrol oleh variabel umur, jenis kelamin, pendidikan, pekerjaan, wilayah tempat tinggal dan pulau tempat tinggal, serta variabel yang berinteraksi dengan konsumsi alkohol. Konsumsi alkohol mempunyai dampak yang signifikan terhadap cedera disebabkan kecelakaan lalu lintas. Hal ini sesuai dengan penelitian yang dilakukan Marsaid et al. (2013) bahwa terdapat hubungan yang bermakna antara pengendara mabuk dengan kejadian meninggal akibat kecelakaan lalu lintas. Mengemudi setelah mengonsumsi alkohol meningkatkan risiko terjadinya kecelakaan lalu lintas dan keparahan dari kecelakaan tersebut (WHO, 2018). Mengonsumsi alkohol menurunkan beberapa elemen penting untuk keselamatan mengemudi, seperti penglihatan dan reflex, penilaian terhadap perilaku berisiko seperti kecepatan dan sulit untuk melaksanakan aturan keselaman (menggunakan seat belt dan helm) (Pan American Health Organization, 2018).

Risiko cedera disebabkan kecelakaan lalu lintas berhubungan bermakna dengan jenis kelamin laki-laki, tingkat pendidikan tinggi, kelompok bekerja, tinggal di perkotaan, dan domisi di Pulau Sulawesi. Penelitian terkait menyebutkan bahwa laki-laki lebih berisiko 4-5 kali untuk mengalami kecelakaan lalu lintas dibandingkan perempuan (Suriyawongpaisal, 2003). Risiko kecelakaan lalu lintas laki-laki lebih tinggi 1,7 kali dibandingkan perempuan (Bener, 2009). Kecelakaan terkait keparahan cedera banyak terjadi pada status pendidikan tinggi dan tinggal di perkotaan (Muratore, 2016). Kecelakaan banyak terjadi pada masyarakat yang memiliki pendidikan tinggi, bekerja, tinggal di perkotaan karena tingginya produktivitas dibandingkan kelompok lainnya (Bawah, 2014). Pulau Sulawesi termasuk yang tinggi kepadatan penduduknya terutama di beberapa kota besar. Kemudian juga terdapat lokasi rawan kecelakaan yaitu jalan trans Sulawesi yang merupakan jalan nasional yang mengakomodasi pergerakan antar kabupaten/kota sehingga tumbuh pemukiman sekitar jalan bersamaan dengan aktivitas lainnya seperti sekolah, berjualan dan lain-lain (Fisu, 2019). Manusia sebagai salah satu penyebab kecelakaan merupakan perpaduan kondisi fisik pengendara dan perilaku ketika berkendara (Suraji, 2010). Tingginya angka konsumsi alkohol tentu juga mempengaruhi perilaku berkendara di Pulau Sulawesi.

Dalam penelitian ini tidak ada perbedaan risiko cedera karena kecelakaan lalu lintas pada interaksi antara konsumsi alkohol dengan usia, jenis kelamin, pekerjaan dan wilayah tempat tinggal.
Peningkatan probabilitas risiko cedera karena kecelakaan lalu lintas terlihat pada interaksi konsumsi alkohol dengan kelompok responden lakilaki dewasa dan tinggal di perkotaan yang mengonsumsi minuman beralkohol. Responden muda lebih berisiko mengonsumsi alkohol (Katyal, 2014) dan prevalensi orang yang minum alkohol lebih tinggi pada laki-laki daripada perempuan (Takahasi, 2017). Prevalensi orang yang minum alkohol di pedesaan lebih tinggi dari perkotaan (Pribadi, 2017). Hal ini berbeda dengan temuan penelitian ini.

Temuan berbeda terlihat pada interaksi konsumsi alkohol dengan variabel pendidikan, pekerjaan, dan pulau domisili. Probabilitas risiko cedera disebabkan kecelakaan lalu lintas semakin meningkat pada kelompok pendidikan rendah, tidak bekerja, dan berdomisili di Pulau Maluku dan Papua yang mengonsumsi alkohol. Responden yang memiliki pendidikan rendah lebih berisiko mengonsumsi alkohol (Katyal, 2014). Semakin rendah jenis pekerjaan maka semakin tinggi konsumsi minuman keras (Santoso, 2017). Pengangguran mendorong untuk minum di rumah dan mudah terpengaruh oleh iklan dan "pelarian dari kenyataan" (Rajput, 2019).

Tingkat konsumsi alkohol di Maluku dan Papua termasuk yang paling tinggi di Indonesia. Jenis minuman beralkohol yang banyak dikonsumsi responden di Pulau Maluku dan Papua adalah minuman tradisional (54\%). Sopi merupakan minuman tradisional masyarakat di Ambon yang tingkat konsumsinya cukup tinggi. Menurut penelitian Lourens (2016), konsumsi sopi tinggi karena adanya sikap negatif (mendukung kebiasaan mengonsumsi sopi) mengenai kebiasaan mengonsumsi sopi, ketersediaan sopi, keluarga yang mengonsumsi sopi dan teman yang mengonsumsi sopi. Sementara di Papua, jenis alkohol tradisional yang banyak dikonsumsi adalah sagero.

\section{KESIMPULAN DAN SARAN}

\section{Kesimpulan}

Penelitian ini menyimpulkan bahwa terdapat hubungan antara konsumsi alkohol dengan cedera akibat kecelakaan lalu lintas di Indonesia. Risiko cedera akibat kecelakaan lalu lintas semakin meningkat jika yang mengkonsumsi alkohol itu pada laki laki usia dewasa yang tingkat pendidikannya rendah, tidak bekerja, tinggal di perkotaan dan mereka yang berdomisili di wilayah Maluku dan Papua. 


\section{Saran}

Saran yang diberikan peneliti dari hasil penelitian ini di antaranya adalah: (1) Perlu adanya upaya penguatan peraturan mengenai larangan konsumsi alkohol saat mengemudi di Indonesia; (2) perlu adanya upaya penguatan kebijakan dan regulasi terhadap produksi dan distribusi minuman beralkohol yang berorientasi pada kesehatan (health public policy) dan disesuaikan dengan budaya dan tradisi tiap daerah; (3) perlu pengawasan dan monitoring implementasi peraturan konsumsi alkohol yang dilaksanakan melalui kerjasama pemangku kepentingan yaitu Bappenas, KemenPU, Kemenhub, Korlantas, Kemenkes, Rumah Sakit dan Pihak Asuransi Kecelakaan; (4) perlu upaya peningkatan promosi kesehatan terkait akibat konsumsi alkohol terutama pada penduduk laki-laki remaja dan dewasa, tinggal di perkotaan, pendidikan rendah, yang tidak bekerja, dan berdomisili di Pulau Maluku dan Papua; (5) perlu upaya integrasi data kecelakaan lalu lintas pada pemangku kepentingan yaitu Bappenas, KemenPU, Kemenhub, Korlantas, Kemenkes, Rumah Sakit dan Pihak Asuransi Kecelakaan; (6) perlu sinergi antara Korlantas dan Kementerian Kesehatan untuk meningkatkan mutu data laporan kecelakaan lalu lintas sehingga diskrepansi data antar sumber menjadi semakin kecil dan akurat.

\section{UCAPAN TERIMA KASIH}

Terimakasih kepada Profesor Budi Hidayat yang telah meluangkan waktu memberikan saran dan pendampingan dalam penulisan naskah ini. Serta ucapan terimakasih disampaikan kepada Badan Penelitian dan Pengembangan Kementerian Kesehatan yang telah mengijinkan kepada penulis menggunakan data set Riskesdas 2018 sebagai bahan penulisan artikel ini.

\section{KONTRIBUSI PENULIS}

Khairun Nisa'il Hulwah (KNH) dan Wahyu Pudji Nugraheni (WPN) adalah kontributor utama dalam artikel ini, dengan tugas $\mathrm{KNH}$ melakukan pengembangan ide utama, mengembangkan pendahuluan, mengembangkan metodologi dan melakukan analisis data dan menuliskan hasil. WPN melakukan literature review, mengembangkan metodologi dan diskusi dan mensitesa kesimpulan dan saran. Andi Sari Bunga, Kurnia Sari, Pujiyanto, Budi Hidayat adalah kontributor anggota yang berkontribusi pada pemeriksaan kelengkapan naskah, memberi masukan pada metodologi, kerangka pikir dan diskusi.

\section{DAFTAR PUSTAKA}

Ajie, K. B., Sulistio, H., Suharyanto, A. (2017) Integrasi Sistem Data Kecelakaan Lalu Lintas di Kabupaten Jember. Rekayasa Sipil, Vol. 11 No. 1: 57-64. https://doi.org/10.21776/ub.rekayasasipil.2017.011.01 8

Badan Penelitian dan Pengembangan Kesehatan: Kementerian Kesehatan RI. (2019) 'Hasil Utama Riset Kesehatan Dasar 2018'

Badan Pusat Statistik. (2019) 'Statistik Transportasi tahun 2018'. Jakarta: BPS

Bawah, A. (2014) 'Road Traffic Fatalities - A Neglected Epidemic in Rural Northern Ghana: Evidence from the Navrongo Demographic Surveillance System' Injury Epidemiology Vol1 No 1:22. https://injepijournal.biomedcentral.com/articles/10.118 6/s40621-014-0022-3

Bener, A., Burgut, H. R., Sidahmed, H., Albuz, R., Sanya, R., Khan, W. A (2009) 'Road traffic injuries and risk factors' Californian Journal of Health Promotion Vol 7 No 2: 92-101. https://journals.calstate.edu/ cjhp/article/view/2017

Coats, T. J., Davies, G. (2002) 'Prehospital Care for Road Traffic Casualties', BMJ Vol 324: 1135-1138. http://dx.doi.org/10.1136/bmj.324.7346.1135

Fisu, A. A. (2019). Tinjauan Kecelakaan Lalu Lintas antar Wilayah pada Jalan Trans Provinsi Sulawesi Selatan. PENA TEKNIK: Jurnal IImiah IImu-IImu Teknik Vol 4 No 1: 53-65. http://doi.org/10.51557/pt jiit.v4i1.215.

Hosseinpour, M., Hafshejani, A. M., Aghdam, M. E., Mohammadian M., Maleki, F (2017) 'Trend and Seasonal Patterns of Injuries and Mortality Due to Motorcyclists Traffic Accidents; A Hospital-Based Study' Bulletin Of Emergency and Trauma Vol 5 No 1: 47-52. https://www.ncbi.nlm.nih.gov/pmc/articles/ PMC5316137/

Katyal, R., Bansal, R., Agrawal, V., Goel, K., Chaudhary, V (2014). 'Cross-sectional Study to Acknowledge the Independent Association of the Socio-demographic Determinants of Alkohol Use in an Urban Slum of North India'. International Journal of Preventive Medicine Vol 5 (6): 749-757. https://www.ncbi.nlm. nih.gov/pmc/articles/PMC4085928/

Kurniasih, D., Arninputranto, W. (2013) 'Analisa Perilaku dan Lingkungan Berkendara Sepeda Motor Pada Pelajar SMA di Surabaya Untuk Menentukan Metode Sosialisasi dan Pembelajaran Safety Riding yang Efektif'. Jurnal Pendidikan Profesional Vol 3 No 2: 11-17. http://jurnalpendidikanprofesional.com/ index.php/JPP/article/view/3

Lin, M. R., Kraus, J. F. (2009) 'A Review of Risk Factors and Patterns of Motorcycle Injuries' Accident Analysis And Prevention Vol 41 No 4: 710-722. https://www.sciencedirect.com/science/article/pii/S00 01457509000578

Lourens. (2016) 'Faktor-Faktor yang Berhubungan 
dengan Praktik Mengkonsumsi Sopi (Minuman Alkoholtradisional) Pada Remaja di Desa Tawiri Kecamatan Teluk Ambon Kota Ambon'. Jurnal Kesehatan Masyarakat Vol 4 No 3: 121-131. https://ejournal3.undip.ac.id/index.php/jkm/article/vie w/12829

Mariana, A. T., Dewi, F. S. T. (2018) 'Cedera Akibat Kecelakaan Lalu Lintas di Sleman: Data HDSS 20152016'. Jurnal Berita Kedokteran Masyarakat Vol 34 No 6: 230-235. http://hdss.fk.ugm.ac.id.

Marsaid., Hidayat, M., Ahsan. (2013) 'Faktor Yang Berhubungan Dengan Kejadian Kecelakaan Lalu Lintas Padaling Pengendara Sepeda Motor Di Wilayah Polres Kabupaten Malang'. Jurnal IImu Keperawatan Volume 1, No. 2: 98-112. https://www.jik.ub.ac.id/index.php/jik/article/view/18

Meirinda, D, E. (2017). Faktor-Faktor yang Berhubungan dengan Kecelakaan Lalu Lintas pada Karyawan Pengendara Sepeda Motor di Koperasi Simpan Pinjam (KSP) Sumber Rejeki Blora. Jurnal Kesehatan Masyarakat (E-Journal) Vol 5, No 3, Juli 2017: 240-248. https://ejournal3.undip.ac.id/ index.php/jkm/article/view/17218

Muratore, S., Hawes, L., Farhat, J., Reicks, J., Gipson, J., Beilman, G (2016) 'Riding into the golden years: injury patterns and outcomes of advanced-age motorcycle trauma' American Journal of Surgery Vol 212 No 4: 670-676. https://www.sciencedirect.com/ science/article/pii/S000296101630349X

Nantulya, V. M., Reich, M. R (2002). 'The Neglected Epidemic: Road Traffic Injuries In Developing Countries'. BMJ Vol 324: 1139-1141. Doi: https://www.bmj.com/content/324/7346/1139.short

Pan American Health Organization. (2018) 'Drinking and Driving'. PAHO Publication

Petridou, E., Moustaki, M. (2000) Human Factors in the Causation of Road Traffic Crashes. European Journal of Epidemiology 16: 819-826. https://link.springer. com/article/10.1023/A:1007649804201

Pribadi, E. T. (2017) 'Penyalahgunaan Alkohol di Indonesia: Analisis Determinan, SWOT, dan CARAT'. Journal of Health Science and Prevention, Vol 1 No 1, April 2017: 22-37. http://jurnalfpk.uinsby.ac.id/ index.php/jhsp/article/view/15

Rajput, S. A., Dipsych, Aziz, M.O., Shiddiqui, M. A (2019) 'Sosial Determinants of Health and Alkohol Consumption in the UK'. Epidemiology Biostatistics and Public Health Volume 16 Number 3: e13128-1 e13128-6. http://dx.doi.org/10.2427/13128

Riyadina, W., Subik, I. (2007) 'Profil Keparahan Cedera pada Korban Kecelakaan Sepeda Motor di Instalasi Gawat Darurat RSUP Fatmawati', Universa Medicina Vol 26 No 2: 64-72. http://univmed.org/ejurnal/ index.php/medicina/article/view/297

Santoso, T., Yuniarti, F. A., Rossida. (2017) 'Hubungan Pekerjaan dan Penghasilan dengan Konsumsi Minuman Keras pada Remaja di Ngemplak Seneng Manisrenggo Klaten Jawa Tengah'. Journal of Health Vol 4 No 2: 87-91. Doi: http://journal.gunabangsa. ac.id/index.php/joh/article/view/103

Sulistiyowati, N., Senewe, F. P. (2014). Pola Penyebab Kematian Usia Produktif (15-54 Tahun) Analisis Lanjut dari Pengembangan Registrasi Kematian dan Penyebab Kematian di Kabupaten/Kota di Indonesia tahun 2012. Jurnal Kesehatan Reproduksi Vol 5 No 1, April 2014: 34-37. https://media.neliti.com/media/ publications/105886-ID-pola-penyebab-kematianusia-produktif-15.pdf

Suraji, A., Tjahjono, N., Cakrawala, M., Effendy, S. B (2010) 'Indikator Faktor Manusia terhadap Kecelakaan Sepeda Motor', Jurnal Transportasi Vol 10 No 2: 125-134. http://103.36.68.33/index.php/ ournaltransportasi/article/view/388

Suriyawongpaisal, P., Kanchanasut, S. (2003) 'Road Traffic Injuries in Thailand: Trends, Selected Underlying Determinants and Status of Intervention' Injury Control and Safety Promotion Vol 10 No 1-2: 95-104. http://dx.doi.org/1566-0974/03/1001-2-095

Takahasi, R., Wilunda, C., Magutah, K., Tenambergen, W. M., Wilunda, B., Perngparn, U (2017) 'Correlates of Alkohol Consumption in Rural Western Kenya: A Cross-Sectional Study'. BMC Psychiatry 17: 175. https://link.springer.com/article/10.1186/s12888-0171344-9

Utama, S. U., Magetsari, R., Pribadi, V. (2008) 'Estimasi Prevalensi Kecelakaan Lalu Lintas Dengan Metode Capture-Recapture'. Berita Kedokteran Masyarakat Vol. 24, No. 1: 16-26.: https://core.ac.uk/download/ pdf/295355701.pdf

World Health Organization (2014) 'Injuries and Violence the Facts'. Geneva: WHO

World Health Organization (2018) 'Global Status Report on Alkohol and Health 2018'. Geneva: WHO

World Health Organization (2018) 'Global Status Report on Road Safety 2018: Summary'.[online] tersedia di https://extranet.who.int/roadsafety/death-on-theroads/\#alkohol diakses pada 27 Februari 2020

World Health Organization (2020) 'Road Traffic Injuries' [online] tersedia di https://www.who.int/news-room/ fact-sheets/detail/road-traffic-injuries pada 21 Juli 2020 